\title{
Enforcement Failures and Remedies: Review on State Jurisdiction over Ships at Sea
}

\author{
Jiancuo Qi \& Pengfei Zhang**
}

The 1982 United Nations Convention on the Law of the Sea admitted legislation and enforcement jurisdiction carried out by the flag state. However, the emergence of substandard ships and the growing number of ship accidents at sea indicate that flag state jurisdiction is far from effective. Four aspects of these failures are examined in this paper. Confronted with the failure of flag state jurisdiction, port states have devised a subsidiary remedy to ensure their national interests and restore the effectiveness of flag state jurisdiction. A problem hereunder arises because non-explicit permission was given to port states to prosecute substandard ships. Thus, this paper further analyses four aspects of port state jurisdiction. The authors aim to analyse the failures and remedies associated with state jurisdiction over ships. It reviews the scope and deficiency of state jurisdiction in combatting substandard ships and illicit activities at sea. This paper also addresses the importance of port state control, regional memorandums of understanding and international conventions.

\section{Keywords}

Enforcement Failure, Flag State Jurisdiction, Port State Jurisdiction, UNCLOS, Substandard Ships, States' Motivations

* Corresponding author. Ph.D. candidate at Korea University School of Law, B.A. (DMU), LL.M. (Swansea U.-UK). ORCID: https://orcid.org/0000-0001-5468-2914. The author may be contacted at: qizixin2009@live.cn /Address: Korea University School of Law, 145 Anam-ro, Seongbuk-gu, Seoul 02841 Korea.

** Professor at Dalian Maritime University School of Law. B.A./LL.M (DMU), Ph.D. (Greenwich-UK). ORCID: https:// orcid.org/0000-0002-3860-5019. The author may be contacted at: shippinglaw@163.com/Address: School of Law, Dalian Maritime University, 1 Linghai Road, Dalian, Liaoning 116026, P.R. China. The author may be contacted at: shippinglaw@163.com/Address: 1550 Haigang Avenue, Pudong District, Shanghai 201306, P.R. China.

All the websites cited in this article were last visited on May 12, 2021. 


\section{Introduction}

Shipping is the oldest global industry and continues to play a vital role in the carriage of goods. Indeed, 90 percent of world trade is carried by almost 50,000 ships. ${ }^{1}$ Thus, inevitably, the question of maintaining ocean order and safety has become increasingly significant. Since ancient times, ships have been identified with particular communities through the use of flags and other insignia. A ship's flag visibly identifies its nationality referring to the state's authority and responsibility for the ship. The primary responsibility to safeguard against substandard ships lies with the flag states. Flag state jurisdiction (FSJ) provides one of the principles for maintaining legal order over activities at sea, although its significance has decreased as a consequence of the growth of port and coastal state jurisdiction over the ocean. ${ }^{2}$ Flag states enjoy primary legislative and enforcement jurisdiction over their ships on the high seas, subject to limited exceptions. ${ }^{3}$ FSJ is said to be necessary since the traditional principle of freedom of navigation implies that states should have primary jurisdiction over vessels to preserve order. As stated by Brown, the 1982 UN Convention on the Law of the Sea (UNCLOS) leaves it to the flag state to ensure that ships flying its flag comply with international law through the exercise of what may be described as its 'ordinary' jurisdiction. ${ }^{4}$

In practice, however, the discharge of control duties, most notably by the flag state, has been proven ineffective in detecting and eradicating all substandard ships from seaborne trading, as was witnessed in the case of the San Marco. ${ }^{5}$ The principle that 'only' the flag state exercises jurisdiction over its ships has been questioned in many aspects. First, the definition of 'ship' is not given in the UNCLOS. Thus, the object of FSJ is unclear. Second, FSJ over a ship depends on the ship's nationality or her flag. International law requires there to be a "genuine link" between the ship and the flag state in order to avoid mere administrative formality. ${ }^{6}$ However, it is notoriously difficult to pin down the meaning of genuine link, which is only intended to secure effective implementation of flag state duties. ${ }^{7}$ Third, international law

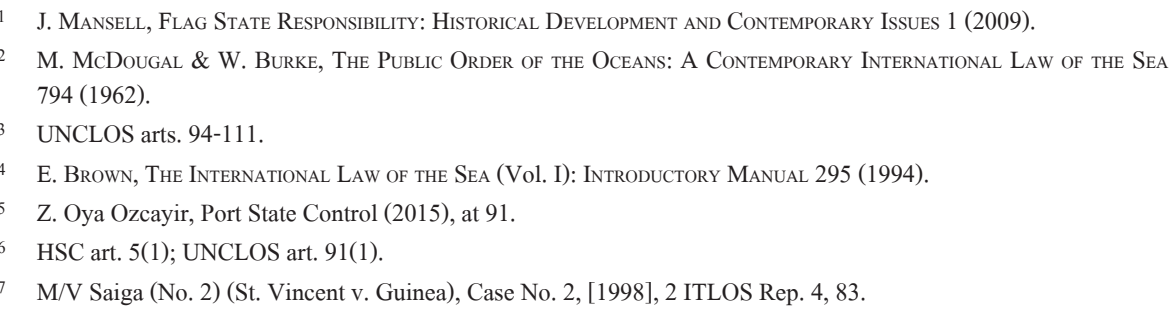


does not require the registration of small ships, thereby raising issues in identifying jurisdiction without nationality. ${ }^{8}$ Finally, non-state actors (NSAs) present the issue of international personality, which is related to the problems of determining a genuine link and granting nationality. ${ }^{9}$

Admittedly, it is nevertheless possible to maintain that FSJ has not failed, but it is far from 'effective.' Confronted with the failure of flag states to adequately regulate ships flying their flags, port states may assume a subsidiary role in exercising jurisdiction by helping to ensure compliance with national and international regulatory efforts. ${ }^{10}$ However, the question remains of how to reconcile this new approach with the principle of sovereign equality that underpins FSJ, since ships located within coastal waters are subject to a more sophisticated combination of flag state and coastal jurisdiction. ${ }^{11}$ In fact, port state jurisdiction (PSJ) may serve not only national, but also global interest. However, it is notable that neither international conventions nor memorandums of understanding (MOUs) give port states the right to prosecute foreign ships for failure of compliance. ${ }^{12}$

The sovereignty of states has been regarded as the basic doctrine of the law of nations that governs the international community. ${ }^{13}$ States enjoy the rights of jurisdiction over their territories and the permanent populations living there. In addition, states are obliged not to intervene in the territories of other states, and the jurisdiction of international tribunals depends on states' consent. ${ }^{14}$ Justice Holmes indicated that the ultimate basis of jurisdiction is "physical power" in McDonald $v$. Mabee. ${ }^{15}$ Also, Beale defined the jurisdiction as "the power of a sovereign to affect the rights of persons, whether by legislation, by executive decree, or by the judgement of a court." ${ }^{\text {"16 }}$ While the concept of jurisdiction originated in the early seventeenth century and was established in the nineteenth century, ${ }^{17}$ state jurisdiction may further be divided into three categories: territorial, quasi-territorial and personal.

8 R. Churchill \& A. Lowe, The Law of the Sea 214 (3d ed. 1999).

9 M Tsamenyi, The Legal Status and Substance of Fishing Entities in International Law: A Note, 37 OcEAn Dev. \& InT'L L. 123 (2006).

10 C. Ryngaert \& H. Ringbom, Introduction: Port State Jurisdiction: Challenges and Potential, 31 Int'L J. Mar. \& Coastal L. 379 (2016).

11 E. Molenaar, Port and Coastal States, in The Oxford Handbook of International Law of the Sea 396 (D. Rothwell \& A. Elferink et al. eds., 2017).

12 UNCLOS art. 228.

13 J. Crawford, Cambridge Companion to International Law 117 (2012).

14 J. Crawford, Brownlie's Principles of Public International Law 528 (9th ed. 2019).

15 Mc Donald v. Mabee, 243 U.S. 90 (1917), https://casetext.com/case/mcdonald-v-mabee.

16 J. Beale, Jurisdiction of Sovereign State, 36 Harv. L. Rev. 241 (1923).

17 The Apollon, 22 U.S. 362, 370 (1824), https://supreme.justia.com/cases/federal/us/22/362. 
Although jurisdiction is primarily exercised on a territorial basis, a state may exercise jurisdiction outside its territory, or there may be the people within its territory, or, in some cases, people outside of its territory, who are immunized from jurisdiction. ${ }^{18}$ The concepts of "port state" and "flag state" relate to different capacities in which a state can act to further or safeguard its own interests, or comply with international obligations.

This article aims to analyse the law of state jurisdiction in combatting substandard ships. It examines the nature, the progress, the scope and the failures of FSJ and PSJ. The authors also address the importance of regional port state control MOUs and international conventions in combatting substandard ships and enhancing maritime safety. To achieve these objectives, cooperation among port authorities is essential, and there is evidence that effective regional port state control regimes result in safer ships and cleaner seas.

\section{Flag State Jurisdiction}

In the past, ships with small tonnage could sail only a short distance off the shoreline; hence, flag states enforced their own standards to maintain safety at sea, while coastal states and port states did not need to concern themselves with maintaining such standards. It has been submitted that FSJ provides the principal approach to maintaining order for maritime activities, although there is a tendency to extend PSJ over maritime zones. Undoubtedly, flag states have the sole responsibility to adopt the rules regulating ships at sea, even when flag states are either unable or unwilling to take the necessary steps to clearly perform their duties. ${ }^{19}$

The absence of effective jurisdiction of flag states over ships flying their flags is not only detrimental to global shipping, but also harmful to the marine environment, particularly when flag states are unable to combat vessel-source pollution. The role of flag state enforcement on the high seas has been considered predominant, while flag states relied on domestic law to regulate ships flying their flags. In 1958, member states of the High Seas Convention (HSC) affirmed FSJ in order to ensure the safety of ships flying the flag of a state. ${ }^{20}$ Over the past decades, member states of

18 Ozcayir, supra note 5, at 61.

19 H.S. Bang, Is Port State Control an Effective Means to Combat Vessel-Source Pollution? An Empirical Survey of the Practical Exercise by Port States of Their Powers of Control, 23 InT'L J. Mar. \& CoAstal L. 715 (2008).

20 HSC art. 10. 
the International Maritime Organisation (IMO) have developed a regulatory regime to conduct surveys and inspections. It is critical to examine the nature of FSJ to understand its legality and further enforce FSJ.

\section{A. The Nature of Flag State Jurisdiction}

It might be conservative to suggest that there is a 'fictional' argument that FSJ originated from territoriality, so that FSJ is a kind of territorial jurisdiction and a ship can consequently be regarded as a floating territory of the flag state. ${ }^{21}$ However, international law seems never to have accepted the notion that a ship is part of the territory of the flag state since, as discussed by Connell, international law does not base its rules on the territoriality doctrine. ${ }^{22}$ Besides, it is clearly indicated that the UNCLOS identifies the area of sovereignty. Article 91 of the UNCLOS, however, confers the nationality on ship only "for purpose of flagging a ship," instead of the territorial extension of flag state. In other words, the International Law Commission adopted the notion of nationality in order to avoid the fiction of ships as territories of flag states. ${ }^{23}$ Moreover, according to Lassa Oppenheim, private vessels are not in fact floating portions of the flag states. ${ }^{24}$

Others hold that flag states are exercising nationality jurisdiction over areas far from their territories through FSJ since a state has the right to grant nationality by way of registration. ${ }^{25}$ In addition, some have justified FSJ on a pragmatic basis, asserting that there must be laws on board a ship, and since these laws cannot change with different ports of call or waters of sail, the law and jurisdiction of the state that owns the ship should be preferred. ${ }^{26}$

\section{B. Flag State Jurisdiction in Progress}

It has been acknowledged that a ship must fly the flag of a state and be subject to the

21 The Case of the S.S. 'Lotus' (Fr. v. Turk.), (1927), P.C.I.J. (Ser. A) No.10, at 25. This was sometimes referred to as the "floating island" theory.

22 During the drafting process, to grant nationality, ships are required to be either part of the state property, or more than half owned by the nationals domiciled in the territory. The nationality of ship is of the characteristic that identical with territory of state. See D. O'Connell, International LaW 800 (Vol. II, 1982).

23 Report of the International Law Commission covering the work of its seventh session, [1955] 1 Y.B. Int'l L. Comm'n, U.N. Doc. A/2934/1955. See also R. Duputy \& D. Vignes, A Handbook on the New Law of the Sea 407 (1991). The International Law Commission adopted that resort to fiction of territoriality was unnecessary.

24 Judicial Committee of the Privy Council, Chung Chi Cheung v. The King, 33(2) Am. J. Int'L L. 382 (1939).

25 M. Baker, et al, Jurisdiction over Vessel-Source Pollution, 30 Rec. Ass'N B. City N.Y. 231 (1975).

26 Lauritzen v. Larsen, 345 U.S. 571, 585 (1953). 
jurisdiction of that state. This has been treated as an essential adjunct to the principle of freedom of the sea because the absence of authority over ships on the high seas would lead to maritime disorder. ${ }^{27}$ Since ancient time, the flag of a ship has been regarded as a visible form of identification which indicates the allegiance of the ship and the application of law to it. Rules of ownership may have arisen from the practice of medieval Italian city states. ${ }^{28}$ When the global economy and trade facilitated the development of ocean governance and the modern nation states emerged in the 16th and 17th century with the consolidation of legal principles, the exclusive jurisdiction of flag states began. ${ }^{29}$

In this course, the concept of nationality has been used to decide which states have the right to exercise jurisdiction with responsibility for the activities of ships at sea. ${ }^{30}$ The flag of a ship has been identified as a marker of the ship's belonging to the flag state, which was also regarded as a means of facilitating private maritime claims. ${ }^{31}$ All this was important to maintain the order over the oceans. ${ }^{32}$

Traditionally, flag states largely relied upon unilateral domestic law to regulate ships flying their flags. By the early twentieth century, the right of states to grant nationality was generally recognized, ${ }^{33}$ although the precise scope of this right has been still developing. Article 10 of the HSC first recognized the right of a state to set out specific conditions for granting its nationality and to fly its flag to ships. It refers to necessary measures to ensure the safety of ships flying the flag of a state. ${ }^{34}$ The Asya ruled that a ship without a nationality has no right to freedom of navigation. ${ }^{35}$ Eventually, the right of states to determine which ships would fly their flags and to set conditions were internationally recognized under the first $\mathrm{HSC}^{36}$ and ultimately under the UNCLOS. ${ }^{37}$

The UNCLOS reaffirmed the responsibility and expanded the role of flag states. Flag states enjoy exclusive jurisdiction over ships flying their flags when the ships are

27 Brown, supra note 4, at 287.

28 R. Coles \& E. Watt, Ship Registration: Law and Practice 3 (2d. 2013).

29 R. Abarnes, Flag States, in The Oxford Handbook of International Law of the Sea 385 (D. Rothwell \& A. Elferink et al. eds., 2017).

30 D. Konig, Flag of Ships, in Max Plank Encyclopedia of Public International Law 2 (R. Wolfrum ed., 2009).

31 Coles \& Watt, supra note 28, at 3.

32 Konig, supra note 30 , at 385.

33 C. Colombos, International Law of the Sea 250 (1961).

34 HSC arts. 5 \& 10.

35 Naim Molvan v. Attorney General for Palestine (The Asya), 81 Lloyd Law Rep. 277.

36 HSC art. 4.

37 UNCLOS arts. 90-91. 
sailing on the high seas. ${ }^{38}$ Article 58(2) of the UNCLOS further grants the rights of flag states to exclusive economic zones (EEZs). The International Tribunal for the Law of the Sea (ITLOS), in the $M / V$ Saiga (No.2), adjudicated that: "determination of the criteria and establishment of procedures for granting and withdrawing nationality to ships are matters within the exclusive jurisdiction of the flag State." 39 Accordingly, flag states are under the obligation to exercise effective jurisdiction in administrative, technical and social matters over ships flying their flags. ${ }^{40}$

\section{The Scope of Flag State Jurisdiction in International Law}

The flag state exercises both prescriptive and enforcement jurisdiction over any ship flying its flag, wherever the ship is located. However, any other states that undertake enforcement actions, such as detention, arrest, or inspect the ship, are required to obtain permission from the flag state, which is regarded as a waiver of the exclusive jurisdiction of the flag state. ${ }^{41}$ Apart from the exception provided in the UNCLOS, the right of navigation is accepted as an important substantive right of flag states. Other states are not permitted to intervene into the ships flying the flag of any sovereign state $^{42}$ while sailing on high seas or in the territorial sea of a state. Article 90 confers the navigational right to states, while Articles 17, 38 and 52 grant navigational rights to ship. Therefore, it is reasonable to codify different notions since navigation is mostly operated by commercial entities. More importantly, ships of different types enjoy different rights of navigation. For instance, warships may have no right of navigation in territorial seas, while commercial ships can enjoy the right of innocent passage.

According to Article 94(1) of the UNCLOS, the flag state is obliged to exercise its jurisdiction and control, including prescriptive, adjudicative and enforcement jurisdiction, ${ }^{43}$ over ships flying its flag. Article 94(2) imposes specific duties on the flag state. Among these is the requirement that ships, including their names and particulars, are registered under the flag state; the extent of particulars included in a ship's registration is left to domestic law. ${ }^{44}$ Article 94(3) requires the flag state to

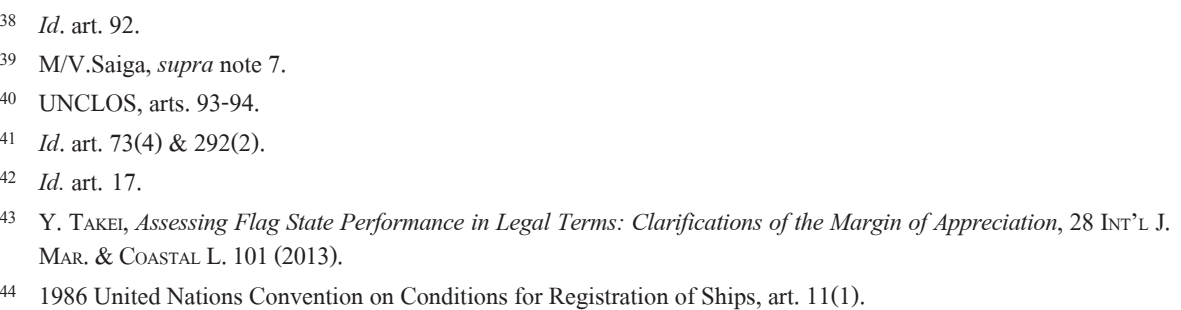


take measures to ensure safety at sea for ships flying its flag; the aspects of safety concerned include, inter alia, construction, equipment, seaworthiness, manning and collision regulations. Such requirement is reinforced by the obligation of the flag state to ensure that its ships are periodically surveyed and equipped with proper navigation equipment and to dispatch qualified crews on board according to regulations. ${ }^{45}$

Maritime agencies of flag states have the overall responsibility for general authorization, certification, monitoring, inspection and enforcement measures. Flag states have the duty to combat polluting activities and must adopt laws and regulations to prevent, reduce and control pollution of the marine environment by ships. ${ }^{46}$ In practice, however, flag states have been far from effective in their performance of these duties. The principle that only flag states should exercise jurisdiction over ships is questioned in the following sections.

\section{Shortcomings of Flag State Jurisdiction}

\section{Emergence of the flag of convenience}

A ship's nationality is the first criterion to determine a state's jurisdiction over the ship. In this regard, the nationality affords a ship the freedom of navigation on the high seas. States grant nationality to ships by registering them in accordance with their domestic laws, which accordingly varies the precise operation among states. Meanwhile, international law has established minimum requirements for granting nationality to ships ${ }^{47}$ thereby giving them the right to fly the flag of a registered state. ${ }^{48}$ In principle, there are three restrictions on granting nationality. First, most agreements assume the registration as a prerequisite for the application of law. ${ }^{49}$ Second, a registered ship cannot be granted another nationality under Article 92 of the UNCLOS which stipulates that ships are required to sail the flag of only one state. Third, a genuine link must exist between the ship and the flag state in order to avoid mere administrative formality. ${ }^{50}$ However, the meaning of genuine link is hard to determine. On the one hand, maritime states try to require a link of ownership or

45 UNCLOS art. 94(4).

46 Id. art. 211(2).

47 For example, during the International Law Commission's work on drafting the 1958 Convention on the High Seas, the view was advanced that State practice had established minimum requirements to be met if the nationality of a vessel was to be recognized.

48 UNCLOS art. 91(1).

49 Konig, supra note 30 , at 385.

50 HSC art. 5; UNCLOS art. 91. 
nationality of the crew as a condition of registration. On the other, however, state practice has not created a rule of custom which has been widely accepted, and the emergence of open registries and the prevalence of flags of convenience reflect the absence of ownership or nationality pre-requisites for registration. ${ }^{51}$

Some scholars oppose the requirement of a genuine link. McDougal and Boczek, for example, have criticized the lack of clarity in the definition of genuine link, describing it as "the most ambiguous criterion ever devised for identifying the national character of a ship.. ${ }^{, 52}$ Others, such as O'Connell, have concluded that the concept of genuine link is difficult to apply since no explicit connection can be established between states and ship-owning companies. ${ }^{53}$

During the drafting of the corresponding provision of the HSC, it was indicated that the requirement of a genuine link is only intended to secure effective implementation of flag state duties, ${ }^{54}$ whereas the absence of a genuine link results in non-recognition. However, this proposal was deleted from the final text. ${ }^{55}$ The UNCLOS, likewise, failed to comprehensively address an absence of a genuine link. ${ }^{56}$ Regarding Articles 94 and 217 of the UNCLOS, which elaborate the duties of flag states in respect of the ships flying their flags, it might be safe to presume that the exercise of effective jurisdiction by flag states over ships is an essential element of the genuine link, as shared by the UN Secretary General in his report. ${ }^{57}$

\section{Unclear definition of 'ship'}

With the increase of human exploration and exploitation at sea, state jurisdiction of offshore craft has become a pressing issue, as there are estimated to be over 7,000 offshore platforms and crafts around the world. ${ }^{58}$ As these crafts are under towage or self-propelled, it has not been indicated that they would neither interfere with navigation, nor create shipping hazards and produce marine pollution. The object of flag state jurisdiction is undoubtedly the ship flying the state's flag. However,

51 Abarnes, supra note 29, at 386.

52 McDougal \& Burke, supra note 2, 794.

53 O'Connell, supra note 22, at 760. McConnell indicated that the relationship between the genuine link, jurisdiction and control and registration remains unclear.

54 M/V 'Saiga' (No 2), supra note 7, at 83.

55 Konig, supra note 30, at 387.

56 M/V Virgina G (Guinea Bissau v Panama), Case No.19, Order of April 14, 2014, ITLOS. Rep. 40, http://www.itlos. org/fileadmin/itlos/documents/cases/case_no.19/judgment/C19-Judgment_14.04.14_corr.pdf.

57 U.N. Doc. A/54/429 (Sept. 30, 1999), https://digitallibrary.un.org/record/319707.

58 E. Techera \& J. Chandler, Offshore installation, decommissioning and artificial reefs: Do current legal frameworks best service the marine environment? 59 MARINE POL'y 53 (2015). 
what legally constitutes a 'ship' under current international law is unclear. Indeed, the scope of 'ship' appears to be critical for identifying the precise object of flag state jurisdiction.

Surprisingly, the UNCLOS does not clearly define 'ship,' and various authorities hold different views on the meaning of this term. For example, the 1995 Merchant Shipping Act (MSA) stipulates: "References in this Convention and in the preceding provisions of this Part of this Schedule to a ship include references to any structure launched and intended for use in navigation as a ship or part of a ship. ${ }^{, 59}$ The key element in this definition appears to be whether the craft is "intended for use as a ship or part of a ship." Notably, the definition does not specify whether the craft should be used exclusively or partly in navigation. ${ }^{60}$ Thus, navigation seems determinative of the scope of flag state control and would normally exclude devices permanently fixed to the seabed, such as oil and gas platforms. However, there are a range of floating and mobile devices which can be used for offshore resource exploitation. Some authorities hold the view that floating platforms would possibly not fall within the definition of 'ship' in paragraph 12 of Schedule 7, Part II of 1995 MSA. ${ }^{61}$

In several cases, British courts have taken the view that an object that performs its main function when it has been affixed to the bottom of the sea should not be regarded as a ship which comes under Admiralty jurisdiction. ${ }^{62}$ Referring to a gas float, Lord Herschell made the following remarks: "It was not constructed for the purposes of being navigated or of conveying cargo or passengers. It was, in truth, a lighted buoy or beacon. The suggestion that the gas stored in the float can be regarded as cargo carried by it is more ingenious than sound." ${ }^{63}$ In conclusion, offshore platforms would firmly fixed to the seabed do not satisfy the definition of a ship.

However, the legal position concerning floating platforms might be rather different. Some semi-submersible rigs operate under their own power in deep waters and usually carry crew, including professional seafarers, on board. ${ }^{64}$ In Merchants'

59 MSA 1995, pt. II, 12 of Schedule 7. Similar definition can be found at: 1954 International Convention for the Prevention of Pollution of the Sea by Oil, art. 1; 1972 International Regulations for Preventing Collisions at Sea, Rule 3(a); 2006 Maritime Labor Convention, art. 2.

60 B. Soyer, Pollution at Sea: Law and Liability 64 (2013).

61 P. Griggs \&. R. Williams et al. (eds.), Limitation of Liability for Maritime Claims 90 (4th ed. 2005).

62 Wells v. Owners of Gas Float Whitton (No 2) [1897] A.C. 337 (HL), 343.

63 Id.

64 Likewise, jack-up rigs, although their legs remain in contact with the seabed during drilling, are capable of being moved from one location to another even within the same field. 
Marine, ${ }^{65}$ the court indicated that a pontoon was not a ship, although it was fully capable of movement and moved from time to time in order to operate in different locations. More recently, in $R$ v. Goodwin ${ }^{66}$ and Steedman v. Schofield, ${ }^{67}$ the court stressed that movement should be motivated by a need to perform a precise function and emphasized that a ship is not necessarily self-propelled. It seems that these authorities tend to accept that the term 'ship' includes oil rigs and moveable crafts. However, problems are likely to arise if such crafts are classified as ships. Calculating their gross tonnage constitutes the main difficulty and further complications arise from the need to determine whether the pipeline attached to the oil rig should be treated as a part of ship..$^{6}$

In certain circumstances, the UNCLOS tackles this issue significantly. For example, Article 92 states that ships are under the exclusive jurisdiction of their flag states while sailing on the high seas, but "installations and structure" are under the jurisdiction of coastal states when they are located in the coastal states' $\mathrm{EEZs}^{69}$ or continental shelves. ${ }^{70}$ In any case, coastal state jurisdiction must adhere to the limits set forth in Part II, Section 3 of the UNCLOS. Therefore, the relevance of FSJ depends on the location of the ship, the nature of its activities, and the scope of application as defined in the relevant conventions. ${ }^{71}$

\section{Non-state actors in international law.}

The idea that only states exercise jurisdiction over ships has been questioned in terms of the role of NSAs (e.g., in the case of how the concept of genuine link and the right to grant nationality operate). A classic example is Taiwan, which is not recognized as an independent nation. Taiwan often requires the permission of the central people's government of China in Beijing to participate in international organisations, but it

65 Merchants' Marine Insurance Co Ltd v. North of England Protection \& Indemnity Association (1926), 25 Lloyds Law Rep. 446, https://intl.westlaw.com/Link/Document/FullText?findType=Y\&serNum=1926023707\&pubNum=999\&orig inatingDoc=I23820800E42811DA8FC2A0F0355337E9\&refType=UC\&originationContext=document\&transitionTyp $\mathrm{e}=$ DocumentItem\&contextData $=$ (sc.Search).

66 R v. Goodwin [2005] EWCA Crim. 3184. The Court of Appeal (Criminal) held that the phrase "used in navigation" is confined to vessels which are used to make ordered progression over the water from one place to another.

67 Steedman v. Schofield [1992] 2 Lloyd Law Rep. 163, at 166. "Navigation" was judicially defined as the "nautical art or science of conducting a ship from one place to another."

68 A critical question in that case will be whether the pipeline could be treated as a part of a ship. If so, further complications will be inevitable when it comes to calculating the tonnage.

69 UNCLOS art. 60.

$70 \quad$ Id. art. 80.

71 A. Lowe, Ships, in International Courts and the Development of International Law 294 (N. Boschiero et al. eds., 2013). 
actually operates its own flag representing regional entity. Since Taiwan was expelled from the UN, it has not been able to participate in negotiations to conclude oceanrelated international agreements and their joint actions, ${ }^{72}$ although it has participated in global or regional organisations as a governmental representative. ${ }^{73}$ In this sense, a non-state party could obtain an international legal personality under contemporary international law. ${ }^{74}$

It is submitted that concerns about the unequal treatment of "non-state entities" in the international society is superfluous. Taiwan's adoption of the 1995 Fish Stocks Agreement and employment of "fishing entity capacity" is a successful example of such entity. ${ }^{75}$ Here, "fishing entity"76 is not "state entity." However, its status as a "non-state entity" has paved the way for Taiwan to participate in decision-making processes. In this course, Taiwan has been able to incorporate itself into the work of the international community and protect its interests.

\section{Failure to define unflagged or stateless ship}

Small ships are not required to register it under international law. ${ }^{77}$ Since these ships are still subject to the jurisdiction of the relevant states, this can generate practical problems, especially when they engage in activities such as "illegal, unreported and unregulated" (IUU) fishing or irregular maritime migration. ${ }^{78}$ Moreover, ships without nationality are exposed to greater risk, especially in finding the state entitled to exercise diplomatic protection and due regard for the human rights of the crew on board.

Ships flying two or more flags may be assimilated to stateless ships. ${ }^{79}$ Article 110 of the UNCLOS prescribes that any state may board and inspect a vessel suspected of being stateless. However, neither the UNCLOS nor the 1988 UN Narcotics

72 Y.H. Song, The Role of Taiwan in Global Ocean Governance, in Regions, InStitutions ANd LAW Of THE SEA: STUdiES IN Oceans Governance 293 (H. Scheiber \& J.H. Paik eds., 2013).

73 N.T. Hu, Fishing Entities: Their Emergence, Evolution, and Practice from Taiwan's Perspective, 37 OcEAN DEv. \& INT'L L. 156 (2006).

74 CRAWFORD, supra note 14, at 115.

75 Both the UNCLOS and the 1995 Fish Stocks Agreement allow entities to sign, ratify, or accede. Article 305(1)(c),(d) and (e) of the UNCLOS are explicitly referenced in Article 1(2)(b)(i) of the 1995 Fish Stocks Agreement.

76 For the background and text of the Code of Conduct for Responsible Fisheries, see the official website of the Code of Conduct for Responsible Fisheries on the FAO (Fishing Entities), http://www.fao.org/figis/servlet/ static?dom $=$ org $\& \mathrm{xml}=\mathrm{CCRF}$ prog. $\mathrm{xml}$.

77 UNCLOS art. 94(2)(a).

78 M. den Heijer, Europe and Extraterritorial Asylum, ch. 6 (2012).

79 UNCLOS art. 92(2). 
Convention $^{80}$ directly address whether or not a stateless ship can be seized. On the one hand, a stateless ship may be seized by any state since no states will protect the ship, as witnessed in the practices in the United States and occasionally in the United Kingdom. ${ }^{81}$ On the other, further jurisdictional nexus and permissive rule are required to seize a stateless ship. ${ }^{82}$ Although the UN Narcotics Convention stipulates action against stateless ships to suppress illicit activities, the permissive jurisdiction to prescribe and prosecute offences on board is difficult to grant. ${ }^{83}$ Indeed, the Convention provides that "this convention does not exclude the exercise of any criminal jurisdiction established by a party in accordance with its domestic law." ${ }^{\prime 4}$ However, this could not be a justification for state to exercise jurisdiction in general international law. ${ }^{85}$

The lack of clear indication of a right to seize stateless ships might be crucial, if one state seizes a stateless ship on the high seas, while other states are not able to exercise diplomatic protection over it. ${ }^{86}$ However, the statements of nationals on board the ship might be able to make a claim on their behalf. ${ }^{87}$ In addition, if the crew have the same nationality as the interdicting ship, the interdicting state can exercise jurisdiction based on the same nationality principle. ${ }^{88}$

\section{Port State Jurisdiction in International Law}

The prosecution of ships is considered the outstanding characteristic of PSJ. It is not limited to the maritime zones of a state, but prosecutes ships for offences beyond a state's maritime zones under Article 218 of the UNCLOS. Although port state Convention), 28 I.L.M. 497 (1989). 369. The US Coast Guard has statutory powers to seize stateless vessel and the Federal Court has consistently upheld the view that US drug-smuggling law can be applied against stateless vessels on the high seas irrespective of any direct nexus between the conduct and the United States.

82 Australian legislation permits the search of certain stateless shipping vessels on the high seas but not their seizure or the arrest of persons aboard: Fisheries Management Act (Cth) (No. 162 of 1991), s. 87H.

83 D. Guilfoyle, Shipping Interdiction and the Law of the Sea 17 (2009).

84 UN Narcotics Convention, art. 4(1)(b)(ii).

85 Id. art. 4.(3).

86 The Asya, supra note 35 , at 369.

87 A. Lowe, Jurisdiction, in International Law 335 (M. Evans ed., 2006).

88 Guilfoyle, supra note 83, at 18. 
regulation has existed since the 1923 Geneva Convention on the International Regime of Maritimes Ports, ${ }^{89}$ the concept of PSJ was not expressly articulated until the 1973 Inter-Governmental Maritime Consultative Organisation (IMCO) Conference, ${ }^{90}$ in which the US submitted a draft to grant port states the power to enforce the violation of applicable international rules and standards. However, Article 218 of the UNCLOS does not adopt this proposal.

Before the 1970s, port states could exercise limited jurisdiction over foreign ships, denying entry to and imposing conditions on foreign ships based on customary international law as well as some guidelines provided by international conventions. ${ }^{91}$ Because Article 211 of the UNCLOS presumes the existence of PSJ, no further definition has been given. Rather, it sets conditions for ships entering a port. ${ }^{92}$ This stipulation can be justified by territorial jurisdiction since every state enjoys complete sovereign jurisdiction. The Permanent Court of International Justice (PCIJ) confirmed in Lotus that a state cannot exercise its power over another state. ${ }^{93}$ In this regard, jurisdiction is certainly territorial. When foreign ships enter a port, they place themselves within the territorial sovereignty of the port state. This was upheld by the International Court of Justice (ICJ) ruling in the Nicaragua case that: " ... by virtue of its sovereignty ... the coastal state may regulate access to its ports." ${ }^{94}$ However, since ships are to a certain extent self-contained units and subject to the laws of the flag state at all times, coastal states only enforce their laws in cases that involve their own interests, ${ }^{95}$ such as peace or the good order of local ports, and custom or immigration offences.

Exceptions for port states to exercise jurisdiction over foreign ships outside their maritime zones are based on treaties rather than customary international law. However, the extraterritorial jurisdiction of port states over pollution offences is subject to the pre-emption of flag states under Article 228 of the UNCLOS.

\footnotetext{
89 The Convention on the International Regime of Maritimes ports (adopted on December 9 1923; entered into in force July 26, 1926) 58 L.N.T.S. 287 (1926).

90 Inter-Governmental Maritime Consultative Organization (current IMO).

91 MARPOL art. 4(2).

92 UNCLOS art. 211(3).

93 S.S.Lotus, supra note 21.

94 Military and Paramilitary Activities in and Against Nicaragua (Nicar. v. U.S.), Judgment, 1986 I.C.J. Rep. 14, 111 (June 27).

95 T. Hillier, Source Book on Public International Law 254 (1998).
} 


\section{A. Port State Jurisdiction under Article 218 of the UNCLOS}

Under Article 218 of the UNCLOS, port states have the power to investigate foreign ships in their ports in respect of any violation of international laws and global standards. However, such enforcement jurisdiction of port states is significantly curtailed, and it cannot be overstated that PSJ in the EEZ is hampered by the preemptive rights of flag states, which can pre-empt legal proceedings for any violation of rules. Article 218 prescribes that the flag state and the state affected shall decide whether a request is needed or not; the port state is not allowed to institute a proceeding unless there is a request from the flag state and the affected state. ${ }^{96}$ For the affected state, proceedings are allowed if the violation has caused or is likely to cause pollution to its maritime zones. The port state is obliged to undertake an investigation if there is a ship voluntarily within its port, or at the request of another state for a discharge violation. ${ }^{97}$ The port state is also obliged to suspend proceedings and transfer security at the request of another state for a discharge violation that has occurred within its maritime zones. ${ }^{98}$ Transmitting evidence and financial security are thought to ensure effective flag state prosecution.

As discussed above, flag states enjoy exclusive jurisdiction over ships flying their flags on the high seas. However, FSJ is not always successful. Article 218 is intended to provide port states with great power to enhance the enforcement of international laws and standards. In this sense, Article 218 is considered innovative since it goes far beyond traditional concept of sovereignty, which only aims to enforce within its territory. ${ }^{99}$ However, Article 218 only applies to the case of discharge violation, tested by the "applicable international rules and standards," which differ from the generally accepted rules and national laws. Moreover, Article 218 requires the ships' 'voluntary' entry into port. Thus, it is arguably accepted that ships entering a port by force majeure or in distress, or to save life and property, might be excluded from PSJ. In all cases, however, port states consider the peace of their country and the good order of their ports significantly. ${ }^{100}$ 


\section{B. The Nature of MOUs in International Law: Treaties or Soft Laws?}

It is necessary to examine the strength of MOU imposed on its member states since a Memorandum expresses a convergence of will between the parties, rather than creating a legal commitment. ${ }^{101}$ Payoyo ${ }^{102}$ has argued that the Paris MOU is a treaty as per Article 2 of the 1969 Vienna Convention of Law of Treaties (VCLT), which defines a treaty as "an international agreement concluded between States in written form and governed by international law, whether in a single instrument or in two or more related instruments and whatever its particular designation." ${ }^{103}$ It is vital to note that the main characteristic of a treaty is that it is a legally binding agreement.

However, phrases such as "have reached the understanding" and "Each Authority will" in the Paris MOU indicate that the parties may not intend it to be binding. ${ }^{104}$ Moreover, participants in the Paris MOU agreed that the document was not to be binding. ${ }^{105}$ Similar wording can be found in other regional MOUs. For instance, the Tokyo MOU states: "the Memorandum is not a legally binding document and is not intended to impose any legal obligation on any of the Authorities."106

Therefore, considering its non-binding character, an MOU seems, to some extent, to play the role of "soft law," a term which refers to recommendations and guidelines that are "deemed to lack requisite characteristics of international normativity, but ... are capable of producing certain legal effects."107 Although some soft law has the similar capacity with hard law, ${ }^{108}$ not all soft law has the potential to ultimately become binding.

The Paris and Tokyo MOUs are considered to be among the most successful regional MOUs, with a high number of powerful states involved. However, the parties in some regions lack the infrastructure and financial capacity to effectively operate MOUs. The variation among MOUs inevitably leads to situations in which substandard ships move to regions where port state control (PSC) is exercised less aggressively. Due to the absence of formal structures, it is possible that disparities

\footnotetext{
101 H.S. Bang \& D.J. Jang, Recent Developments in Regional Memorandums of Understanding on Port State Control, 43 OCEAN Dev. \& InT'L L. 172 (2012).

102 P. Payoyo, Port State Control in the Asia-Pacific: An International Study of Port State Jurisdiction 77 (1993).

103 VCLT art. 2(1).

104 Port state Control inspections in the Paris MoU, https://www.parismou.org/inspections-risk/library-faq/memorandum (2021).

105 E. Molenaar, The EC Directive on Port State Control in Context, 11 Int'L J. Mar. \& Coastal L. 246 (1996).

106 Tokyo MoU, http://www.tokyomou.org/doc/Memorandum\%20rev18.pdf.

107 A. Boyle \& C. Chinkin, The Making of International Law 229 (2007).

108 J. Gold, Strengthening of the Soft International Law of Exchange Arrangements, 77 Am. J. InT'L L. 481 (1983).
} 
could grow in the future. ${ }^{109}$ Thus, a formal system has been advised to reduce disparities between regional MOUs.

\section{Enforcement of Port State Jurisdiction as a Subsidiary Remedy}

PSJ is a term often used in international public law to refer to a state's exercise of its right to visit ships in its maritime zones. The PSC system has been developed through two approaches worldwide. The first involves regional MOUs, modelled on the Paris MOU, which-although it is a regional regime to eliminate the operation of substandard ships-has been the most restrictive and harmonized system of PSC. ${ }^{110}$ The second is the US's PSC system. Since no agreement is specifically dedicated to PSC in the US, there is no conclusive list of conventions enforced by the US Coast Guard under its PSC program. ${ }^{111}$ The following section analyses several aspects of PSJ, including its development, nature and limitations, as well as motivations for states to exercise PSJ.

\section{A. Port State Jurisdiction in Motion}

Before 1950, as recognized in both French and Anglo-American historical practice, foreign ships sailing in port areas were subject to the jurisdiction of the port states. Accordingly, the British Government stated at The Hague Codification Conference in 1930 that "the State is entitled to exercise jurisdiction over a foreign merchant ship lying in its port." 112 However, port states restricted the jurisdiction over the internal affairs of ships. Except when ships disrupted the peace and good order of local ports, the port states avoided unnecessary interference, taking into account of the practical needs of states. International standards were rudimentary before 1950 such as the Load Line Convention ${ }^{113}$ and the International Convention for the Safety of Life at

109 E. Molenaar, Coastal State Jurisdiction over Vessel-Source Pollution 124 (1998).

110 Paris MoU: Organization, https://www.parismou.org/about-us/organisation.

111 Z. Oya Ozcayir, The use of port state control in maritime industry and application of the Paris MOU, 14 OCEAN \& Coastal L. J. 219 (2009).

112 D. Anderson, Port State Powers in the Modern Law of the Sea, in Modern Law of the Sea: Selected Essays 268 (D. Anderson ed., 2008).

113 International Convention on Load Lines (adopted Apr. 5, 1966; entry into force July 21, 1968), 640 U.N.T.S. 133 (1968), https://reaties.un.org/doc/Publication/UNTS.Volume\%20640/volume-640-I-9159-English.pdf. 
Sea (SOLAS). ${ }^{114}$ The number of these standards were relatively limited in number and scope.

Since the mid-twentieth century, open registries system has become increasingly popular. Ships are registered in foreign ports to benefit from financial and other advantages they provide in comparison with registration in the place of residence. This has inevitably led to the proliferation of flags of convenience, which make it possible to escape manning requirements imposed by certain flag states. In response to this problem, it was suggested that the US Labour Management Relations Act, which sets out national standards for crewing, be invoked regarding foreign ships that visit the US ports. ${ }^{115}$ However, the US Supreme Court ruled that port states should not disturb internal affairs and reversed the decision of the New York Court. ${ }^{116}$ As concern for non-compliance with international standards grows, IMCO has made valiant efforts, ${ }^{117}$ especially in the prevention of marine pollution. These efforts include requiring ships of a state party to carry an oil record book that can be inspected by port states.

As international standards increase, ships in full compliance with the international rules bear a higher cost than those that do not meet these standards. Moreover, the market is seemingly indifferent to compliance with standards, while competition for service and freight is harsh. Thus, it seems that the flags of convenience will continue to grow. However, Article 16 of the 1958 Convention on the Territorial Sea and the Contiguous Zone recognizes the right of port states to take necessary measures to prevent breach of conditions when ships enter into their internal waters. ${ }^{118}$

Since 1970, as oil spills case such as the Torrey Canyon have drawn the attention of coastal states, measures have been taken to prevent marine pollution, including the revision of the rules for port states inspecting ships under the Collision Regulations. ${ }^{119}$ Responding proposals to pollution were advanced at the London Conference, ${ }^{120}$ but it ultimately decided to leave jurisdictional issues aside. Accordingly, the 1973 International Convention for the Prevention of Pollution of Ships (MARPOL) gives a

\footnotetext{
114 International Convention on Safety of Life at Sea of 31 May 1929 (UK Treaty Series No. 34, 1932), Cmd.4198.

115 The LMRA, sometimes referred to as the "Taft-Hartley Act," applies to all employees whose labor-management relations is subject to the jurisdiction of the National Labor Relations Board.

116 Incres Steamship Co Ltd v International Maritime Workers Unions: 372 U.S. 24 (1963).

117 International Maritime Consultative Organization (IMCO: later renamedIMO).

118 Convention on the Territorial Sea and the Contiguous Zone 1958, art. 16(2).

119 Convention on the international Regulations for Preventing Collisions at Sea 1972.

120 Convention on the Prevention of Marine Pollution by Dumping of Wastes and Other Matter, the official website of IMO, https://www.imo.org/en/OurWork/Environment/Pages/London-Convention-Protocol.aspx.
} 
broad definition of 'jurisdiction.' 121

The concept of PSJ was considered at the first substantive session of the UNCLOS Conference, when the Greek delegation proposed that a port state could prosecute ships suspected of violation of agreed rules on pollution prevention on the request of a flag state. ${ }^{122}$ At the following session in $1975{ }^{123}$ the UK, sponsored by nine European delegations, presented justification for improving enforcement, highlighting difficulties in obtaining evidence of illegal discharge and stopping ships in sea lanes. ${ }^{124}$ In the following year, 1976, the International Labour Organisation (ILO) adopted Convention No. 147 on Merchant Shipping (Minimum Standards). ${ }^{125}$ Article 4 of Convention No. 147 authorises the port state to "take measures to rectify any conditions on board which are clearly hazardous to safety and health," in addition to reporting the matters of non-compliance to flag states. While the new proposal was witnessed in the 1970s, developments were made in the 1980s, particularly with the adoption of the Paris MOU and the UNCLOS in 1982.

In the aftermath of the Amoco Cadiz disaster, a meeting of shipping states in Europe was held in Paris in 1982, where the Paris MOU on PSC was adopted as an instrument to establish an effective system of PSC and ensure compliance with international standards. ${ }^{126}$ All port states that were parties of the meeting agreed to inspect ships against the agreed standards and ensure that deficiencies were rectified. ${ }^{127}$

The second stage of development in the history of PSJ was the adoption of the UNCLOS in 1982. The UNCLOS recognizes that the jurisdiction of the port state to establish conditions for entering port, ${ }^{128}$ but ships cannot be prosecuted outside a particular maritime zone of the port state for suspected violation of international standards. ${ }^{129}$ It also authorises the port state to undertake physical inspection if

121 International Convention for the Prevention of Pollution from Ships of 2 November 1973, as modified by the Protocol of 1978 (adopted Nov. 2, 1973; entered into force Oct. 2, 1983), 34 U.N.T.S. 3407; 1340 U.N.T.S. 61 (1983).

122 The official record of UNCLOS, 3rd. Sess., U.N. Doc. A/CONF.62/C.3/L.4, https://legal.un.org/diplomaticconferences/ 1973_los/docs/English/vol_3/a_conf62_c3_15.pdf.

123 Id. 19th Mtg., U.N. Doc. A/CONF.62/C.3/SR.19, https://legal.un.org/diplomaticconferences/1973_los/docs/english/ vol_4/a_conf62_c3_sr19.pdf.

124 Id., U.N. Doc. A/CONF.62/C.3/L/24, https://legal.un.org/diplomaticconferences/1973_los/docs/english/vol_4/a_ conf62_c3_124.pdf.

125 Convention No.147 on Merchant Shipping (Minimum Standards) (adopted Oct. 29, 1976; entered into force Nov. 28, 1981), 1259 U.N.T.S. 335 (1981), https://www.ilo.org/dyn/normlex/en/f?p=NORMLEXPUB:12100:0::NO::P12100_ ILO CODE:C147.

12621 I.L.M. 1 (1982). The scope of the arrangements was later expanded to include, for example, amendments to the Load Lines Convention (1988), the SOLAS Convention (1988), and the STCW Convention (1978).

127 Anderson, supra note 112, at 274.

128 UNCLOS art. 211(3).

129 Id. art. 218. 
any aspect of the ship's condition does not correspond with the documents it is carrying. ${ }^{130}$ It has been submitted that Article 218 contains an innovative concept of PSJ. As Birnie and Boyle have observed, "it is ... a novel development in the law of the sea to confer jurisdiction on port states in this way." 131

Further progress occurred in two years with the adoption of the International Convention on Standards of Training, Certification and Watchkeeping for Seafarers (STCW) ${ }^{132}$ which gives port states the right to prevent ships from sailing before deficiencies are rectified, especially when those deficiencies found to be dangerous to persons, property and the environment according to the agreed standards in paragraph 3. Several developments have made progress at both the regional and global levels. For example, the IMO Assembly adopted Resolution A.472(18) in $1993^{133}$ and Resolution A.787(19) in $1995^{134}$ to establish the procedure for PSC in respect of the safety of ships and pollution prevention. ${ }^{135}$ George Kasoulides has argued that PSC can be a regime to counter-balance FSJ by referring to the extension of substantial laws and practice into foreign jurisdiction. ${ }^{136}$

\section{B. The Nature of Port State Jurisdiction: Territoriality or Extraterritoriality?}

Port states may provide subsidiary prescription and play an enforcement role in offsetting the inadequate jurisdiction of flag states over their ships in foreign ports. Further, port states may apply international rules and domestic laws to exercise jurisdiction over foreign flag ships. However, questions may arise on the territorial nature of PSJ since the exercise of PSJ has effects beyond the scope of port and national jurisdiction.

There is a tendency to believe that the territoriality principle and international agreements justify the assertion of PSJ. Accordingly, assertion based on territoriality is considered legitimate, while that based on extra-territoriality is considered

\footnotetext{
130 Id. arts. $220 \& 226$.

131 P. Birnie \& A. Boyle, International law and Sustainable Development: Past Achievements and Future Challenges 334 (2001).

132 Convention on Standards of Training, Certification and Watch keeping for Seafears (STCW), https://www.imo. org/en/OurWork/HumanElement/Pages/STCW-Conv-LINK.aspx.

133 Procedures for the Control of Operational Requirements Related to the Safety of Ships and Pollution Prevention, IMO Res. A.742(18) (Nov. 17, 1993), https://wwwcdn.imo.org/localresources/en/KnowledgeCentre/IndexofIMOResolutions/ AssemblyDocuments/A.742(18).pdf.

134 IMO, Port state Control, https://www.imo.org/en/OurWork/IIIS/Pages/Port\%20State\%20Control.aspx.

135 Supra note 133.

136 G. Kasoulides, Port State Control and Jurisdiction: Evolution of the Port State Regime 104 (1993).
} 
illegitimate. ${ }^{137}$ Even when the exercise of PSJ has effects outside the territory, such jurisdiction is territorial in terms of its intent. Territoriality with different underlying interests might be treated as extra-territorial, but it has been widely recognized in both law of jurisdiction and general international law. ${ }^{138}$ Since ports are part of states' territory, port states enjoy residual territorial jurisdiction and exercise territorial sovereignty within ports, and they have the right to set conditions to visit ships and carry out inspections. Therefore, foreign ships have no right to access ports unless they have fulfilled their legal obligations to port states. Moreover, a growing number of international agreements have affirmed the existence of such residual jurisdiction. ${ }^{139}$

It is necessary to distinguish between port state's enforcement jurisdiction and prescriptive jurisdiction. A port state can enforce rules within its territory. Within prescriptive jurisdiction, the scope of a state's enforcement power is limited; the state can only enforce its regulations when it has prescriptive rights. Therefore, the scope of prescriptive jurisdiction is a significant issue. ${ }^{140}$

Since a state has jurisdiction in its territory, there seems to be little doubt about a state's prescriptive jurisdiction over activities in its ports. Churchill and Geir indicate that this extends to Clean Development Mechanism (CDM) standards, ${ }^{141}$ since inadequate compliance standards threaten the safety of shipping and the environment in ports. ${ }^{142}$ Such a position will almost as a matter of course produce extraterritorial effects. Moreover, it can also be justified on the basis of functional quasi-territoriality. ${ }^{143}$ However, for activities outside maritime zones, territoriality cannot be the ground of jurisdiction, while international agreements provide the basis for jurisdiction in these areas. ${ }^{144}$ Since the port state can exercise a wide range of powers holistically, it is essential to address the difference between PSC and PSJ. Although the relevant articles of the UNCLOS do not distinguish both principles, the following chapter addresses the importance of PSJ in combatting substandard ships.

137 RYNGAERT \& RingBOM, supra note 10 , at 381.

138 H. Buxbaum, Territory, Territoriality, and the Resolution of Jurisdiction Conflict, 57 Aм. J. ComP. L. 635 (2009).

139 Molenaar, supra note 11 , at 6.

140 RYNGAERT \& RingBOM, supra note 10 , at 383.

141 R. Churchill \& U. Geir, Autonomous Institutional Arrangements in Multilateral Environmental Agreements: A little-noticed phenomenon in international law, 94 Aм. J. INT'L L. 624 (2000).

142 J. Scott, Extraterritoriality and Territorial Extension in EU Law, 62 Aм. J. ComP. L. 88 (2014).

143 E. Molenaar, Options for Regional Regulation of Merchant Shipping Outside IMO, with particular reference to the Arctic Region, 45 OcEAN Dev. \& InT'L L. 228 (2014).

144 S. Kopela, Port State Jurisdictional, Extraterritoriality and the Protection of Global Commons, 47 OCEAN DEv. \& INT'L L. 97 (2016). 


\section{The Role of Port State Jurisdiction as an Alternative Remedy}

The term "port state jurisdiction" is a broader concept than the term "port state control." The latter is best understood in light of the rationale of regional MOUs. Admittedly, PSJ concerns the power of port states to prosecute and fine ships when breaches of regulations are found. By contrast, PSC limits the power of port states to take administrative measures, when there is no prosecution in the case of PSC for alleged breaches of legislation. ${ }^{145}$ Rather, port states detain ships in port until their deficiencies are corrected or order ships to the nearest port for repairs. The crucial element of PSJ is to exercise the enforcement jurisdiction and the judicial jurisdiction, rather than prescriptive jurisdiction, since the authorities of port states derive their power to enforce PSC from domestic law.

Meanwhile, port state's authorities are required to play a more proactive role to compensate for the inadequacy of flag state control. Therefore, those conventions prescribe related provisions ${ }^{146}$ to confirm that port authorities can conduct inspections of ships in their ports or offshore terminals. PSC involves inspection in respect of international rules and standards that foreign vessels must abide by. ${ }^{147}$ It is worth noting that compliance differs from 'implementation' and 'effectiveness.' Specifically, compliance means that "commitments entered into by a state are fully effectuated in practice" $" 148$ and requires actions at both a domestic and an international level. By contrast, 'implementation' refers to "the adoption by states of domestic laws and regulations pursuant to relevant international obligation," and 'effectiveness' emphasizes the achievement of the aims of existing international rules. ${ }^{149}$ Therefore, it is appropriate to distinguish PSC from other regimes because the object of PSC is to establish effective regimes to take action against substandard ships.

PSC officers inspect foreign ships in a wide range of aspects, and take corrective measures if any deficiencies are found. ${ }^{150}$ Article 220 of the UNCLOS allows port states to inspect ships when there are grounds to believe that a violation has occurred.

\footnotetext{
145 Bang, supra note 19, at 717.

1461982 Paris MOU on Port State Control; 1993 Tokyo MOU on Port State Control (Asia-Pacific region); 1996 Caribbean MOU; 1997 Mediterranean MOU; 1998 Indian Ocean MOU; 1999 Abuja (West and Central African Region) MOU; 2000 Black Sea MOU; and 2004 Riyadh (Arab states of the Gulf) MOU.

147 J. Hare, Port State Control: Strong Medicine to Cure a Sick Industry, 26 GA. J. INT'L \& Comp. L. 571 (1997).

148 R. Wolfrum, Means of ensuring compliance with and enforcement of international environmental law, in COLLECTED Courses of The Hague Academy of International Law: Recueil des Course 272 (1999).

149 L. Schiano di Pepe, Port State Control as an Instrument to Ensure Compliance with International Marine Environmental Obligations, in International Maritime Environmental Law 146 (A. Kirchner ed., 2003).

150 G. Kiehne, Investigation, Detention and Release of Ships under the Paris Memorandum of Understanding on Port State Control: A View from Practice, 11 InT'L J. Mar. \& CoAstal L. 222 (1996).
} 
If a crew is not familiar with the operations relating to the prevention of pollution from garbage for regular change of the crew, ${ }^{151}$ for instance, failure to observe vital shipboard procedures may lead to ship-source pollution. ${ }^{152}$ In this case, rectifications may be required before sailing if the deficiencies are serious. As detention is a powerful measure, flag states must be promptly informed if observed deficiencies lead to detention. ${ }^{153}$ Nonetheless, detention can be disastrous for the owner or operator of the detained ship. On the one hand, a history of detention is recorded on the website of the relevant MOU and can be checked by other parties, such as charterers and classification societies. ${ }^{154}$ On the other, owners face financial difficulties if their ships are detained, and all costs related to inspection are charged to the owners' accounts. The UNCLOS provides guidelines for PSC, and similar provisions regarding substandard ships are given in STCW, ILO, SOLAS and the International Ship and Port Facility Security (ISPS) Code.

As the primary international convention addressing the prevention of shipsource pollution at sea, MARPOL $(73 / 78)^{155}$ represents about 99 percent of the gross tonnage around the world. ${ }^{156}$ Article 5(2) of MARPOL provides that a port state may conduct PSC to verify whether a ship carries certificates which prove that it adheres to the MARPOL regulations. However, these inspections are limited to verifying the certificates unless there are clear grounds to believe that a ship does not substantially comply with the requirements. Article 6 of MARPOL grants the port state the right to inspect the suspected ship while it is in its ports, but the power of enforcement remains with the flag state. In this respect, it is accurate to describe port states and coastal states as active facilitators in enforcing the Convention. ${ }^{157}$

The role of port states appears to be far more significant in suppressing crimes at sea, especially piracy and armed robbery. As the UNCLOS entitles all states to board ships suspected of piracy on the high seas, states are encouraged to cooperate to the fullest possible extent to repress piracy. ${ }^{158}$ Nonetheless, hurdles created by Article 101

151 IMO, supra note 134.

152 Molenaar, supra note 105, at 254.

153 A. Rakestraw, Open Oceans and Marine Debris: Solutions for the Ineffective Enforcement of MARPOL Annex V, 35 Hastings Int'L \& Comp. L. Rev. 410 (2012).

154 Ozcayr, supra note 111, at 237.

155 In 1973, IMO adopted the International Convention for the Prevention of Pollution from Ships, now known universally as MARPOL; amended by the Protocols of 1978 and 1997 and kept updated with relevant amendments.

156 IMO, The Protection of the Marine Environment, http://www.imo.org/en/OurWork/Environment/PollutionPrevention/ Pages/Default.aspx.

157 MARPOL art. 6(2)-(5).

158 UNCLOS art. 100. 
of the UNCLOS itself undermine the exercise of universal suppression of piracy at sea. ${ }^{159}$ Conversely, acts that occur in territorial seas are excluded from the suppression regime on piracy. Therefore, regional cooperation and interventions by coastal states play a significant role in overcoming the hurdles to repressing illegal acts. For example, the UN Security Council Resolution 1816 adopted in 2008 has proved to be successful in calling for nearby coastal states to cooperate to deter acts of piracy and armed robbery off the coast of Somalia. ${ }^{160}$ During the process of suppression, coastal states could undertake all necessary measures at the request of the Somalia Transitional Federal Government. Such activities could be considered extensions of Somalia's sovereignty. ${ }^{161}$

As PSC activities are basically of a regional nature, states are gathered into a binding MOU to ensure the exercise of PSC. Effective and harmonized enforcement of existing rules and standards-as opposed to prescription in concert with new standards-is considered the defining characteristic of MOUs. Various advantages have resulted from the establishment of regional MOUs, which have developed regional PSC to enhance the efficiency of port state inspection and to reduce repetitive inspections of foreign ships through harmonization and the sharing of information among states. ${ }^{162}$ Abundant evidence proves that the involvement of port states in controlling and supervising ship standards has significantly contributed to maritime safety and security, as well as the prevention of marine pollution. ${ }^{163}$ So far, about nine MOUs cover nearly all maritime regions of the world. Although the US is not a member of any regional MOU, the US Coast Guard has its own PSC program. ${ }^{164}$

\section{Is Port State Jurisdiction a Sufficient Remedy?}

PSJ provides subsidiary remedies for the enforcement failures associated with FSJ. Nevertheless, the normative relationship between PSJ and FSJ remains unclear.

159 Id. art. 101(a)(1). It provides: "Piracy consists of any of the following acts: (a) any illegal acts of violence or detention, or any act of depredation, committed for private ends by the crew or the passengers of a private ship or a private aircraft, and directed: (i) on the high seas, against another ship or aircraft, or against persons or property on board such ship or aircraft; ..." Under the Article 58(2) of the UNCLOS, the relevant provisions on piracy are also included in the regime for the EEZ.

160 U.N. Doc. S/RES/1816 (June 2, 2008), https://www.securitycouncilreport.org/un-documents/document/somalia-sres-1816.php. See also IMO, International Conference on the Suppression of Unlawful Acts against the Safety of Maritime Navigation (SUA) (2021), https://www.imo.org/en/KnowledgeCentre/ConferencesMeetings/Pages/SUA.aspx.

161 Yaodong Yu \& Yue Zhao \& Yen-Chiang Chang, Challenges to the Primary jurisdiction of Flag States over Ships, 49 OCEAN Dev. \& InT'L L. 97 (2018).

162 H.S. Bang \& D.J. Jang, Recent Developments in Regional Memorandums of Understanding on Port State Control, 43 Ocean Dev. \& Int'l L. 171 (2012).

163 Soyer, supra note 60, at 277.

164 Bang, supra note 162. 
While the UNCLOS is silent on PSJ, Article 92(1) of the UNCLOS provides that ships are under the exclusive jurisdiction of flag states subject to international treaties or conventions between states. Thus, it is reasonable to maintain that FSJ ultimately limits PSJ. However, as Arron Honniball has convincingly argued, ${ }^{165}$ Article 92 does in fact prescribe enforcement jurisdiction on the high seas, but it is not relevant to PSJ, which is enforced in the port of a state. ${ }^{166}$ It implies that flag states maintain a stronger relationship with the operation of ships and can protest the overreaching exercise of PSJ. Nevertheless, as the capacity of port states to gather data increases, flag states may lose primary jurisdiction over ships flying their flags as PSJ expands. ${ }^{167}$

It is acknowledged that the UNCLOS imposes limitations on PSJ. In particular, Article 211(3) gives pre-conditions to foreign ships entering ports for the reduction and control of pollution of the maritime environment. ${ }^{168}$ In addition, states are obligated not to abuse their rights under the Convention and to act in good faith during the exercise of PSJ. ${ }^{169}$ Other limitations arise from traditional commercial law, particularly trade law and regulations related to the World Trade Organisation (WTO), since PSJ may either enhance or restrict international trade to some extent. According to Robin Churchill, even when a breach of the WTO rules is found, it can be remedied by the public policy exceptions of Article XX of General Agreement on Tariffs and Trade (GATT), ${ }^{170}$ which gives effect to multilateral agreements and improves the compatibility of GATT. It resembles "common concern" rather than a regime imposed for protectionist purposes. ${ }^{171}$

Besides the limitations arising from international rules, abundant shortcomings can be found in the operation of PSJ. For instance, the port state cannot supervise ships' design and construction standards. Also, subtle deficiencies in ships' equipment are hard for port states to investigate and correct during ships' short periods of stay in port. In this aspect, the argument that PSJ supersedes FSJ in combatting substandard ships is far from reasonable. PSJ can neither substitute for FSJ, nor entirely replace FSJ due to the limitations and shortages identified. ${ }^{172}$

\footnotetext{
165 N. Honniball, The Exclusive Jurisdiction of Flag States: A Limitation on Pro-active Port States?, 31 InT'L J. MAR. \& CoAstal L. 499-530 (2016).

166 Ryngaert \& Ringbom, supra note 10, at 386.

167 Id.

168 UNCLOS art. 211(3).

169 Id. art. 300.

170 R. Churchill, Port State Jurisdiction Relating to the Safety of Shipping and Pollution from Ships-What Degree of Extra-territoriality?, 31 Int'L J. Mar. \& COASTAL L. 443 (2016).

171 Ryngaert \& Ringbom, supra note 10, at 387.

172 A. Behnam \& P. Faust, Twilight of Flag State Control, 17 OCEAN Y.B. 167 (2013).
} 
Moreover, the primacy of FSJ has not been diminished while the threat of marine pollution has pushed the international community to adopt more robust measures in dealing with polluting incidents than before. A remarkable example is the Intervention Convention, ${ }^{173}$ which sets a higher threshold for coastal states to undertake measures to prevent polluting incidents. Article V of the Intervention Convention requires that the danger is imminent and expected to have harmful consequences. Meanwhile, the measures must be "proportionate to the damage" and coastal states are not allowed to "unnecessarily interfere with the rights and interests of the flag state." " These conditions are not considered easy for port states and coastal states to meet priority to take action. Article 218 of the UNCLOS also restricts PSJ. In this regard, the pollution violation of a ship must be assessed as per "international rules and standards" and a standard of "clear ground for believing violation of laws" is required for the coastal state to take enforcement action against a ship passing through its territorial sea or EEZ. Article 218 further affirms that the flag state plays a dominant role in the prevention of vessel-source pollution. The dominant role of the flag state is even clearer in anti-piracy activities and the fight against terrorism at sea, while other states respond under the consent of the flag state. There is little indication that they can take action without the approval of the flag state under current international rules. ${ }^{175}$

\section{Conclusion}

Human activities at sea were fairly limited in the past. As the marine environment is paid attention more importantly, people in the 21st century are more interested in marine protection. This process involves balancing the competing interests between those who use the ocean and assert their freedom of navigation, and border the ocean and claim to protect the marine environment. By its nature, the codification will strike a balance between these conflicting interests. This process is formidable because it requires a decision as to which interest shall enjoy priority. While the primary responsibility for exercising effective jurisdiction over ships belongs to the flag state, PSJ has also proven to be critical in combatting substandard ships.

173 International Convention Relating to Intervention on the High Seas in Cases of Oil Pollution Casualties 1969, 1155 U. N.T.S. 331 (1975), https://cil.nus.edu.sg/wp-content/uploads/formidable/18/1969-International-Convention-relating-toIntervention-on-the-High-Seas-in-Cases-of-Oil-Pollution-Casualties-1.pdf.

174 International Convention Relating to Intervention on the High Seas in Cases of Oil Pollution Casualties 1975, art. V.

$175 \mathrm{Yu} \&$ Zhao \& Chang, supra note 161, at 97. 
Contemporary international law provides various regimes conferring rights to port states and coastal states to exercise jurisdiction so as to enhance ships' safety and reduce marine pollution. However, the current arrangements are far from impeccable, although PSC has proven to be the most effective systems for controlling shipping. On the one hand, port states and coastal states lack the authority to take punitive or corrective enforcement actions. As discussed above, international rules have established a high threshold, which is quite difficult to satisfy. This substantially weakens the subsidiary function of port states in enforcing their jurisdiction. On the other, as the current PSC regimes are not yet fully developed, some of the measures provided are of a voluntary nature; there is thus a high chance that these measures are not implemented effectively. ${ }^{176}$

The adoption of IMO Assembly Resolution A.682(17), entitled "Regional Cooperation in the Control of Ships and Discharges,"177 reflected a broad recognition that PSJ could effectively address inadequate flag state performance if exercised collectively. ${ }^{178}$ The resolution implicitly acknowledged the added value of the Paris MOU and further contributed to the creation of a global network of regional PSC arrangements. ${ }^{179}$ However, mere geographical coverage does not mean that other MOUs will achieve the performances in Paris and Tokyo. A positive sign is that efforts have been undertaken by IMO, together with ILO and Food and Agriculture Organization (FAO). Meanwhile, regional PSC arrangements are cooperating with one another. ${ }^{180}$ In December 2013, the IMO Assembly adopted a mandatory member state audit scheme and the IMO Instruments Implementation Code, which replaced the voluntary audit scheme binding member states. It also put pressure on flag states to improve their compliance with international standards. ${ }^{181}$ Thanks to the constant efforts of FAO, a legally binding Port State Measures Agreements, under which port states are increasingly involved in governance regimes, entered into force in $2016 .{ }^{182}$

For port states, exercising jurisdiction is not only a technical act, but usually

\footnotetext{
176 J. Swan, Port State Measures to Combat IUU fishing: International and Regional Developments, 7 SustaInable DeV. L. \& POL'y 38 (2006).

177 Regional co-operation in the control of ships and discharges, IMO Res. A.682(17) (Nov. 6, 1991), https://puc.overheid. nl/nsi/doc/PUC_1405_14/1.

178 Molenaar, supra note 11 , at 368.

179 IMO, supra note 136.

180 Procedures for Port State Control, IMO Res. A.1052(27) (Dec. 20, 2011), https://www.classnk.or.jp/hp/pdf/ activities/statutory/ism/Imo/A.1052(27).pdf.

181 IMO Instruments Implementation Code (III Code), IMO Res. A.1070(28) (Dec. 4, 2013), https://wwwcdn.imo.org/ localresources/en/KnowledgeCentre/IndexofIMOResolutions/AssemblyDocuments/A.1070(28).pdf.

182 FAO, Agreement on Port State Measures to Prevent, Deter and Eliminate Illegal, Unreported and Unregulated Fishing (entered into force June 5, 2016), http://www.gc.noaa.gov/documents/gcil_k6339e.pdf.
} 
associated with the assertion of their own interests and claims to authority. Consequently, states will undoubtedly tend to exercise jurisdiction over port affairs for their own interests by means of both political and economic power. ${ }^{183}$ However, PSJ is no longer only a regime that maximizes the interests of port states. Rather, it is a developed enforcement machinery, which imposes its will on foreign-flagged ships and states. As argued by Sophia Kopela, ${ }^{184}$ "the concept of global commons [is] an issue of common concern," and states are allowed to resort to PSJ to assert the common interests of other parties. When doing so the fundamental functions of the international regime of the law of the sea can be promoted. ${ }^{185}$ Nevertheless, it is possible to conclude that PSJ is gradually becoming a comprehensive and mandatory regime, and recognizing the interests of the international community is expected to increase due to concern with issues such as maritime safety and security, the marine environment, sustainable fishing and marine biodiversity. Therefore, it may not be long before shipping becomes safer and more efficient.

Received: March 1, 2021

Modified: April 15, 2021

Accepted: May 15, 2021

183 Ryngaert \& Ringbom, supra note 10, at 391.

184 Kopela, supra note 144, at 112.

185 Id. 